\title{
Writing the Naked Body: Sex and Nudity in Nuala Ní Chonchuír's Nude
}

\author{
Máximo Aláez Corral \\ University of Oviedo, Spain
}

Copyright (c) 2016 by Máximo Aláez Corral. This text may be archived and redistributed both in electronic form and in hard copy, provided that the author and journal are properly cited and no fee is charged for access.

\begin{abstract}
This essay looks into the deconstruction of the male gaze and the objectification process around the concepts of nudity and nakedness. Starting from the review of some of Martha Nussbaum's, John Berger's, or Laura Mulvey's main ideas on the topic of the gaze and objectification, a practical analysis of some of the short stories contained in Nuala Ní Chonchúir's Nude (2009) is provided. By so doing, I intend to examine the ways in which conventional objectification phenomena can be turned upside down, challenged or parodied in order to reveal cultural discriminatory undercurrents and offer a new non-objectifying visual and written representation of the naked body.
\end{abstract}

Key Words. Ní Chonchúir, Objectification, Male Gaze, Nude, Naked Body, Feminism.

Resumen. Este ensayo analiza la deconstrucción de la mirada masculina y el proceso de reificación en torno al concepto de desnudez en toda su extensión. Tras plantear un breve repaso de algunas de las ideas planteadas por Martha Nussbaum, John Berger o Laura Mulvey acerca tanto de la mirada como de la reificación del cuerpo, realizo un análisis práctico de algunos de los relatos contenidos en Nude (2009), de la autora irlandesa Nuala Ní Chonchúir. Con este análisis me propongo examinar los modos en los que se pueden desmontar, desafiar o parodiar los modos convencionales de reificación, con el fin de revelar los principales procesos culturales de discriminación y al mismo tiempo ofrecer una representación visual y literaria del cuerpo desnudo nueva y no fundamentada en procesos de reificación.

Palabras clave. Ní Chonchúir, reificación, mirada masculina, desnudo, cuerpo desnudo, feminismo.

\section{Introduction}

John Berger says about the female nude in painting: "She is not naked as she is. She is naked as the spectator sees her" (1972: 50). Berger's work directly addresses the differences between nakedness and nudity, especially when connected with voyeurism, and was one of the first efforts to bring awareness to the phenomenon of objectification - i.e. treating a subject as an object - of women in art. Sexual objectification has been analysed repeatedly from different perspectives, but probably the feminist approach remains the more interesting, even despite the high level of diversity and occasional confrontations deriving from each analysis within the feminist methodological paradigm. Laura Mulvey also established a cornerstone in the critical analysis of the male gaze and objectification of women in Hollywood's classic cinema with her 1975 essay "Visual Pleasure and Narrative Cinema". ${ }^{1}$

1. Mulvey modified and qualified her own analysis later on, in "Afterthoughts of "Visual Pleasure and .\% 
A couple of decades later, Martha Nussbaum (1995) defined the basic ingredients in the production of objectification in her analysis of texts by several authors, ranging from D.H. Lawrence to James Joyce or Henry James. Nussbaum cited seven key factors or notions for a process of objectification to be complete: "instrumentality", "denial of autonomy", "inertness", "fungibility", "violability", "ownership", and "denial of subjectivity" (1995: 257). In between Mulvey's and Nussbaum's essays other feminists released their own analyses of objectification in contemporary cultural manifestations. This was the case of Andrea Dworkin and her book Pornography: Men Possessing Women (1979), or Catherine Mackinnon's Pornography and Civil Rights: A New Day for Women's Equality (1988), written in collaboration with Dworkin. The topic I would like to focus on in this essay, however, is not so much pornography as objectification and the way(s) in which the latter is connected to the representation of nudity, as exemplified in Nuala Ní Chonchúir's ${ }^{2}$ collection of short stories Nude (2009). ${ }^{3}$

Far from shying away from such a delicate subject-matter, Ní Chonchúir boldly explores the possibilities of representing/narrating the naked body (both male and female), in tight connection with a preference for the sexual

\footnotetext{
./ Narrative Cinema' Inspired by Duel in the Sun" (1981). In this article she extended her explorations around the gaze to include the way in which women spectators where addressed by classic Hollywood films, stressing the fact that the film narration can be so masculine that the female spectator be "out of key" and fail to get from the film any pleasure of her own (122).

2. I will use the author's Irish name throughout the text, since that was the name she used when she wrote this collection. It should be noted, though, that she has recently begun to use the anglicized version of her surname - Nuala O'Connor - to sign her current literary works.

3. For the sake of simplicity I will focus only on some of the stories contained in the book, even though most of my conclusions might also be applied to those stories that are not mentioned in the essay.
}

reading of the body as it is gazed upon by a far from innocent gendered "gaze". It is precisely this particular way of depicting and interpreting the naked body that interests me, for both sexual objectification and the (fe)male gaze are combined in Nude to produce a piece of literature that unexpectedly reverses the orthodox normative dichotomies concerning nudity and at the same time blurs gender differences between male and female "ways of seeing". Can we, therefore, identify a 'genuine' non-objectifying gaze in Ní Chonchúir's stories? Probably the best way to find an answer to this question would be to briefly examine some aspects of both (sexual) objectification and the male gaze, in order to reach some insight for the analysis of these evasive stories.

\section{The Sexualized Gaze: Objectified Bodies}

Much has been written about the 'male gaze' as regards the process of objectification of women - especially regarding the representation of women in cinema. Although the work I intend to analyse is a literary piece and not a film, the theoretical framework on the 'male gaze' may prove useful for the purposes of my research: thus, it is my contention that Ní Chonchúir plays with the representation of the naked body in an ambiguous way in order to bring out a heteronormative discriminatory approach found both in literature and in the visual arts. By so doing she manages to turn conventional assumptions around nudity and nakedness into a scenario filled with dysfunction, consequently establishing a new ground for a nonnormative - and non-discriminatory representation of both women and men.

Laura Mulvey and John Berger, as has already been stated, devoted some of their finest reflections to explain the way in which women are objectified in Hollywood cinema and in European visual arts, respectively. Mulvey used Lacanian psychoanalytic theory to develop her theory, while Berger used Marxism to highlight the way in which traditional oil paintings depicting female nudes overlap as regards form, content and intentions with contemporary advertising: women become objects of the (male) gaze, while men 
are invariably positioned as subjects - i.e. those who actively look. Being deprived of any kind of agency women can easily be labelled "objects of possession" of the male subject, the one who traditionally commissions, paints and eventually owns both the artistic object (the painting) and the image contained therein (the female nude), for his own pleasure and satisfaction.

Several of the stories in Ní Chonchúir's collection deal with actual nude paintings or with the process of creating nude paintings: in almost all such instances, the works of art that are mentioned are or have been created by male painters and depict female nudes. "Roy Lichtenstein's Nudes in a Mirror: We Are Not Fake!", "Ekphrasis", "Madmoiselle O'Murphy" or "Juno out of Yellow" are all excellent examples of stories where a "painted" female nude (i.e. an "object") is given a voice and an agency they were lacking in their original paintings: thus the 'nude' becomes the 'naked body'. There are exceptions to this norm, of course: in "Jackson and Jerusalem", as we will see, an old female painter has a young man sitting for her as a model to include a male nude in one of her paintings.

The female protagonist in Hollywood melodramas - Mulvey states - is unable to achieve a stable sexual identity, which creates "a sense of the difficulty of sexual difference" (123). In the short stories contained in Nude there is a large number of male and female characters, each with their own voices and personalities. I have come to observe, however, that although the female characters' voices and depictions are rich in complexity and diversity, the male ones occasionally tend to sound slightly contrived and somewhat androgynous.

4. In "Mademoiselle O'Murphy" an old woman (Mary Louise O'Murphy) reflects on the love affair she had with king Louis XV of France, at a time when she posed nude for Françoise Boucher's painting Louise O'Murphy, as well as the rivalry with Madame de Pompadour, the king's 'official' mistress. "Juno out of Yellow" is a story about the making of an allegorical painting, where the painter (the husband) has his wife and daughter pose for him. While the painting is being made, the family receives the visit of a distant acquaintance, who is revealed at the end of the story to be the wife's lover.
While this may be intentional on the part of Ní Chonchúir, it nonetheless reveals an imbalance in treatment that stands out especially when the story is narrated from the point of view of the male character - as in, for example, "Jackson and Jerusalem", "To Drift and to Lift", "In Seed Time, Learn", or "The Woman in the Waves". Narration, in such cases, tends to recreate a sort of "passive" masculine voice, as if the story was narrated by an undefined gendered voice pretending to be masculine. Mulvey's argument about the male gaze is thus reversed here, as far as the narrative voice is concerned, by introducing the female voice as the "normative" and active voice, and the male voice as the deviation from the norm (often verging on the dysfunctional).

As we will see, a further anomaly in this respect, or rather an even clearer hint of dysfunction, can be traced in Ní Chonchúir's stories, for the way in which the acts of both gazing and looking are narrated noticeably challenges the normative subject/object relation. The subjects who look (men or women) simultaneously become objects who are looked at and vice versa, but most importantly the acts of looking or being looked at are problematized by an equally dysfunctional approach, in such a way that neither gazing entitles the gazer any power over the gazed, nor being looked at necessarily implies a submissive or passive position. Interestingly, some of the characters who are looked at - or whose bodies are being looked at, either in the flesh or through a painting develop what bell hooks has called an "oppositional gaze", 5 i.e. the gaze of those supposed to be blind objects, but who nevertheless discover the power of the gaze and long to exert it (Jones 2003: 94).

In Nude, most characters gaze at other characters' naked bodies with a sexually charged look, in such a way that each look mirrors an equally sexually charged depiction of nudity. The naked body, thus, becomes both a means and an end in itself, both an object and

5. Hooks devotes her theory of the "opposing gaze" to the female/male black/white dichotomies, but the concept itself could be applied, in my opinion, to other contexts of power imbalance. 
a subject. At the same time, the contexts in which nudity is narrated are often connected in these stories to very base and raw instincts and impulses, not only defying conventional morals on marriage and relationships but also occasionally touching incestuous attractions, as in "Sloe Wine", 6 a story where two narrative tenses are brilliantly combined. A scene between the two teen characters in the story, who may be "more than cousins" (Ní Chonchúir 2009: 95), is illustrative of the author's bold approach: "She puckered her mouth and eyed him. Ralph closed his eyes and kissed her hard; she let him probe her lips, then she kissed him back. They pulled apart and looked at each other" (2009: 101). In this respect all passions - acceptable and unacceptable - are levelled down and equalled whenever a body (and the sexualized gaze) is involved in the narration.

This "equalizing" effect becomes even more striking if we add the differences in treatment that are conventionally assigned to erotic art and pornography in connection with nudity and that are, once more, challenged in Nude. As Fredrickson and Roberts state: "bodies exist within social and cultural context, and hence are also constructed through sociocultural practices and discourses" (1997: 174). According to Lynda Nead, one such practice tends to be socially and culturally applied to "good" and "bad" representations of the nude erotic art and pornography, respectively (1992: 103). Aesthetics, the basic ingredient of passive contemplation, turns the nude into a "good" and acceptable representation of the body (i.e., it "legitimizes" the nude) in erotic art, whereas functionality in connection to a sexualized depiction of the body turns it into a "bad" or unacceptable representation (as in pornography). The key question here, in either case, is that the "erotic" quality of a given depiction of nudity does not stem in any innate way from the image itself, but is always culturally constructed (Nead 1992: 104). In other words, we are educated into reading certain images as erotic, and others as porno-

6. In "Sloe Wine", two cousins in their teens share a bottle of wine while their mothers remember their own teenage years and the love they shared for a young man with whom both had sexual intercourse. graphic. In terms of the naked body, both erotic art and pornography are ruled by the male gaze, inasmuch as in either case the body becomes an object - for passive contemplation, in the former, and for active sexual arousal, in the latter.

In my opinion, however, the way in which the writing of the body is presented in Nude precisely offers an alternative to the limited relation erotica/pornography. The undermining of the patriarchal male dominance contained in the gaze comes in Ní Chonchúir's stories by means of an unstable (fe)male subjectivity, whereby no gender trait is "natural", fixed or taken for granted. Interestingly, the way in which the male body is narrated in Nude brings to the fore the "'feminization' of the male subject" wielded by Kaja Silverman (1988: 149), as regards the formation of any individual's identity. Again, this destabilizing of patriarchal assumptions about masculinity is particularly evident in those stories narrated from the point of view of a male character "Jackson and Jerusalem" is a clear example of this deconstructing process. Faithful to her ambiguous and often playful narrative meandering, however, Ní Chonchúir also depicts "normative" masculinity and femininity whenever this may suit her purposes; thus, in "Mrs Morison of Haddo" we have an example of both a male and a female character who perform their gender to the letter - precisely in a way that blatantly betrays the masquerade behind the male gaze and the female "to-be-looked-at-ness".

According to Martha Nussbaum objectification can be theorized in the classical feminist sense as the turning of women into "things" (objects), thus depriving them of "self-expression and self-determination"; but it can also be thought of under a more positive light, and, under certain specifications, it may even present "features that may be either good or bad, depending upon the overall context." (1995: 250).

Dworkin defines objectification in a much more straightforward manner: "Objectification

7. "Mrs Morison of Haddo" is a very short story about a pregnant woman posing for her portrait while she tentatively flirts with the painter. 
is ... an internalized, nearly invariable response by the male to a form that is, in his estimation and experience, sufficiently whatever he needs to provoke arousal" (1979: 113). Furthermore, she seems to put the blame of the body becoming an object on the body itself, as far as it is responsible for provoking a given reaction in the watcher. If the body is a cultural construction, the body image must also be created by an individual willingness following a certain set of social and cultural parameters. Thus, on the one hand the individual creates her/his own aesthetic bodily configuration, and on the other hand the watcher helps in the construction of the visual message by completing its meaning and validating it in accordance to its accommodation to the social standards of acceptability. In this respect, desire, as the door leading to pleasure, plays a crucial role.

Curiously enough, Nussbaum's analysis of objectification seems to have more in common with Kant than with Dworkin or Mackinnon. In line with Kant's thoughts, Nussbaum states that whenever sex is implied in the process of gazing/representing the individual, he/she is not treated as a person but as an object for the satisfaction of sexual desire, which means that both men and women alike crave to be objectifiers and objects (1995: 267). It is sexuality, therefore, that prompts objectification by reducing the body to a tool in order to satisfy an appetite. Dworkin and Mackinnon steer away from Kant in this, according to Nussbaum, for both consider female desire in an assymetrical relation to male desire: only women are "turned into something rather than someone" (1995: 268).

Still, becoming an object may have diverse effects for the objectified individual: a woman may go through the process of objectification and end up being "an aesthetic object with an affective price"; but she may also become a thing for the sole purpose of being used for the satisfaction of sexual desire (i.e. as a mere sexual instrument), without any pleasure derived from the contemplation of her beauty (Papadaki 2007: 334-5). Such is the condition of prostitution for Kant, whereas marriage offers an instance of acceptability regarding sexual relationships (Nussbaum 1995: 267, 269). Relationships either inside and outside the scope of marriage prove to be especially productive in Ní Chonchúir's narrative; and it is very often gazing at the naked body that prompts turbulences and moral complexity within those relationships. In this sense, unlike for Kant, for the Irish author marriage - or a normative heterosexual relationship - does not seem to solve the problem of objectification, as long as either in marriage or outside it individuals may use or not other individuals' bodies for their own pleasure and satisfaction. It is the body - the naked body, and the sexual content built around its representation - that ignites the fire of desire which leads to objectification, rather than any specific relationship between men and women. Ní Chonchúir, however, does not expose the objectification process from the safety of narrative distance, but plunges herself - as implied author, in Wayne Booth's terms - into the diegesis of each story, adding a fair dose of moral ambiguity to the narration and making, in line with Nussbaum's argument, the acts of both objectifier and objectified virtually interchangeable.

\section{Writing the Naked Body}

To return to the question I posed at the beginning of this essay, if we want to embark on a fruitful analysis of Ní Chonchúir's stance in the creation of a non-objectifying writing of the body, it is crucial to understand the body as a malleable and ever-changing subject matter, an organic space where no assumptions whatsoever should be taken for granted. The shifting perspectives and points and view, the diverse male/female voices, the flowing of some stories into others, everything in the book seems orchestrated to bring out a rarified overview on the ways people look at and understand other people's bodies, and how the acts of looking, no matter how diverse they may be, are always tightly linked to a desperate need to communicate with and to relate to other human beings.

One of the main ideas in Mulvey's essay on the gaze in classic Hollywood cinema was the destruction of pleasure as a tool to fight objectification deriving from the male gaze (1975: 834). This could be achieved, first, by analysing pleasure and beauty, and then by breaking down "the voyeuristic-scopophilic 
look that is a crucial part of traditional filmic pleasure" (1975: 843). While Ní Chonchúir never adopts such a belligerent feminist position, she does contribute, in her own way, to challenge and question the traditional gaze. By introducing ambiguity and dysfunction in supposedly fixed ways of seeing she weakens the power of the gaze as a tool to reinforce heteronormative relationships. Several of the stories in Nude have to do precisely with tensions arising from the need to find pleasure in the contemplation of the naked body and the clumsiness, inability or inadequacy to handle the feelings provoked by such contemplation.

One such case can be found in "Juno out of Yellow", one of the stories dealing with paintings and nude models. The story is told from the model's daughter's point of view. The mother's body goes through a double process of objectification: as an erotic nude - in a painting created under her husband's gaze - , the woman becomes an aesthetic object (thus accommodating the "legal" and acceptable depiction of nudity); but she is also objectified as a sexual object by the lover's gaze, who looks at her strictly to sate his sexual appetites. Ní Chonchúir smartly disrupts the gazed/gazer unidirectional relation by allowing the wife also to look and gaze at the lover (and probably at her own image in the painting) in a lustful way. The daughter also looks, but her way of seeing runs a parallel course to her father's: she looks at her mother (both her "real" body and the body in the painting) as an aesthetic object. When talking about the painting she says: "He portrayed Mother being helped out of a yellow cloak, her alabaster breasts pouched, her face turned away" (Ní Chonchúir 2009: 117), and shortly after, as she's watching her mother's body in the flesh: "My eyes linger on the bush of hair between her thighs, comparing it mentally to my own sparse sproutings" (2009: 118).

In yet another disruption of convention, the lustful gaze - the one from the lover, we are to imagine - ends up being subtly captured and represented in the painting. At the end of the story the daughter's narrative voice tells us: "Most people haven't realized that there's a third person in the painting. In the mirror, behind Mother and me, you will see a face - a Lebrocquyian ghost of whites, with two sashes of black; nicotine brown smoke rises from this figure, whose mouth is a stretched leer" (2009: 120-1). By rendering the voyeuristic gaze part of the visual diegesis, the male gaze goes through a deconstruction process and is revealed and exposed as part of the objectifying process: the objectifier becomes objectified. The fact that the gazer's gaze is reflected in a mirror could be interpreted as harking back to the fascination resulting from self-contemplation as described in Lacan's "mirror stage". One crucial lesson that we can extract from Lacan's concept is the primacy of the visual during this phase. Vision is, of all senses, the one that performs a greater "distancing function", which means that the subject can distance him/herself from the object (his/her own image reflected in the mirror), "unimplicated or uncontaminated" by its object (Grosz 1990: 38). The other senses seem to implicate the subject to a greater degree in the sensory process, there being a "contiguity between subject and object" (1990: 38). This sensory predominance is especially relevant, in my opinion, if we want to understand the fundamentally visual quality of objectification, and the way binary roles and categories are sanctioned and approved through the visual and its distancing effect active/passive, gazer/gazed, powerful/ powerless, etc. As we will see, even though vision plays a predominant role in most of the stories from Nude, it is often "contaminated" by the interference of the other senses, usually forming sensory nets that turn the body into a complex entity and hamper a straightforward objectification process.

"As I Look", a story that appears roughly halfway in the collection, and can be seen as a paradigmatic compendium of Ní Chonchúir's thoughts on nudity and nakedness, shows, again, the clash between contemplative beauty - as tends to be the traditional reading of the paintings mentioned in the narration, Giorgo de Chirico's Uncertainty of the Poet (1913), and Man Ray's Pisces (1938) - and the actively sexual reading coming out of the female protagonist's gaze. Right at the beginning of the story Ní Chonchúir already gives us a hint on how the body is doubly interpreted in traditional terms: "Naked means unprotected or bare, stripped or destitute. Nude means unclothed, 
or being without the usual coverings ... Being nude is a beautiful thing (supposedly), but to be naked is to be exposed" (2009: 61). These words strongly echo John Berger's assertions in his 1972 essay: "To be naked is to be without disguise ... A naked body has to be seen as an object in order to become a nude ... Nudity is placed on display" (54). Aesthetics, in this respect, stands for a mask, or a disguise, that prevents exposure; thus, a nude can be seen as a sort of dressing, or hiding, the naked body, and infusing the social or moral acceptability that a naked representation of the body is denied. In "As I Look", it becomes clear that both paintings in the gallery are nude - and not naked - depictions of the body. In both cases we have objects to be contemplated for their aesthetic qualities: a fragment of a classical nude statue, placed next to a bunch of bananas (in the case of the De Chirico painting), and a stylized female body placed next to a huge fish (in the case of the Ray painting).

These "objects", nevertheless, are looked at through the protagonist's sexually charged gaze, creating a sense of dysfunction that permeates the whole story and rarefies their supposed original aesthetic effect. Even more strongly than in "Juno out of Yellow", the main female character offers another way of seeing, turning the nude into a naked body, taking it out of the painting's mirror-image and highlighting the raw sensuality lost in the objectification process: "[I]t's all sensuality and food and phallic-ness. The symmetry is uncanny and I suddenly understand that both paintings are about sex" (Ní Chonchúir 2009: 64).

"As I Look" is a story about how the introduction of sexuality problematizes the aesthetic reading of images; but it is also a story about women and men looking and how they gaze at each other. The sexually-charged gaze and reading of nudity is presented under the light of dysfunction in order to reveal the cracks and failures of the fixed heteronormative approach to the depiction of nudity and sexuality (i.e. erotic art and pornography). We get a similar dysfunctional approach to the reading of nudity elsewhere in the collection, in the story titled "Unmothered"; in this case the act of painting and gazing deftly segues into the sexual act and back into the act of gazing, in an uninterrupted narrative flow:

Your husband paints your portrait in the garden. You are naked, standing in the grass, and every breeze makes your skin prickle ... You watch your husband watching you ... It's as if you're looking at yourself, and this life you're anchored in, from somewhere else ... You like to hear your husband's cry, the deep throated sound that means he has released his very self into you ... He looks at you as if from a great distance; you wonder if he can see you (Ní Chonchúir 2009: 14-5).

Whereas both Laura Mulvey and Andrea Dworkin had proposed "radical" solutions to the problem of inequality and discrimination derived from objectification (destruction of pleasure and eradication of pornography, respectively), Ní Chonchúir does not propose any solution, but rather reveals how both the gaze and objectification are complex cultural phenomena that do not necessarily cause inequality or discrimination - at least, not to women only. In this respect, her approach runs closer to Nussbaum's.

In both "Juno Out of Yellow" and "As I Look" the false strength of "normative" or fixed relationships (marriage and orthodox heterosexual relationships) is exposed as soon as the naked body comes into play and sexual instincts are aroused. ${ }^{8}$ In the story that closes the collection, "In Seed Time, Learn", the conflict around the different perspectives on adultery comes to the fore when sex is confronted to love feelings:

'This is a one time thing', I said. 'There's Imogen'.

'Stop freaking out', Dana said, 'I'm not in love with you, Sonny' ... 'I often think about Marty being unfaithful and leaving me. It's a kind of a torture but it keeps up my interest, makes him precious to me'... 'Why, I wonder? So he doesn't get in there first? To prove something to myself? Jesus, it's so tired'

8. The meddling of an "unlawful" body in a normative relationship is especially frequent in Nude: virtually all the stories contain at least one episode of such interference, but the most prominent examples in this respect may be "Madonna Irlanda", "To Drift and to Lift", "Cowboy and Nelly", "Night Fishing”, "Juno Out of Yellow", or "In Seed Time, Learn". 
'It doesn't feel tired. I love being with you', I said.

'But it's a one time thing, right?' (Ní Chonchúir 2009: 129-30).

"Jackson and Jerusalem", the story coming after "As I Look", displays another reversal of conventions: the painter - one of the producers of the gaze - is, this time, a woman (Magda Bolding), and the model a young boy (Jackson). ${ }^{9}$ The way the story is told - from the boy's perspective - damages the canonical objectification process and brings life and individuality to his voice, revealing an alternative to the body becoming an object that does not imply the refusal either to look at the naked body or to be looked at. Again, sex is far from absent in the way the boy's body is gazed at, even though, at first, there's a hint at aestheticism and pleasure in passive contemplation. When she looks at the boy for the first time, the painter remarks his resemblance to other canonical images of nudity: "'Wow', she said, 'hair like a Botticelli cherub" (Ní Chonchúir 2009: 66).

From the start, the roles of gazer and gazed are constantly shifting. Through the boy's first person perspective we get to know how he gazes at the woman and the effect the gaze has on him: "[H]er hair flopped over her shoulder like a mane. I was mortified, her eyes kept landing on me; I fidgeted and looked at the floor, the walls, the ceiling ... She was watching me. I eyeballed her" (Ní Chonchúir 2009: 66-7). The boy's gaze might be understood in a first reading as an "oppositional gaze", as bell hooks described the term; but in my opinion his body has not been conventionally objectified: thus, he is not a "blind" object, and even though his body is being looked at he never fully becomes a thing. If we analyse Magda's behaviour towards Jackson under the light of Nussbaum's seven key notions involved in any process of objectification, we will see that most of them do not

9. Magda Bolding is a character that also appears in the first story in the collection, "Madonna Irlanda", set in her younger years, at a time when she travelled to Paris and modelled in the nude for a colleague painter with whom she had a brief yet intense love affair. appear in this story. The boy retains his autonomy and his subjectivity (he speaks with his own narrative voice and displays full agency in his actions and movements), and there does not seem to be any sense of ownership in the way Magda Bolding (the painter) behaves towards him. Magda treats Jackson, at first, as some kind of pupil and, later, as a friend, but never as a thing, even though it is made clear that his presence in the studio is intended to help her create an image of Jesus Christ - this could be the only notion from Nussbaum's paradigm related to objectification (i.e. "instrumentality") that seems to be de facto applied in the story. At a given point in the narration Magda says: "Artists are like doctors, where the human body is concerned' ... 'Bare flesh is just part of the working day" (2009: 69). In spite of this connection between art and medicine, the way Jackson perceives and narrates Magda's attitude towards him betrays an empathy that goes beyond medical - or artistic - scrutiny, and that speaks of a humane attitude that is very much needed and well-received by the boy, taking into account his degraded low-class background.

There is still another factor which, in my opinion, also weakens the objectification process at work in Magda's and Jackson's relationship, and this is the importance the narrator gives to the other senses apart from vision, specially touch. When Magda meets Jackson for the first time, her need to gaze is coupled with her need to touch: "She took my face in her hands and tilted my head; her fingers were cool and soft, like a doctor's" (Ní Chonchúir 2009: 66); later on in the story this need to touch reappears as if it was a ritual: "She took my hands; I hate anyone touching my skin, but I let her hold on to me, if that was what she wanted" (2009: 68); "She brought my hands to her mouth, kissed my fingers, and said, "Thank you"' (2009: 69); "She ruffed my hair and smiled; her hand landed on my shoulder (2009: 72). Other times tactile qualities are combined with the sense of taste, often in depictions of the abject connected to bodily stuff: "Magda frowned and sucked her pencil; I knew the soggy wooden taste it'd leave in her tongue, the paint chips that'd stick 
to her teeth. I wanted to take it out of her mouth" (2009: 67). We also find this insistence on the tactile quality of the body in "In Seed Time, Learn": "I kissed Dana through a mouthful of Bisou Rose; she pushed some of it into my tongue and we munched the fruit and giggled, juice wetting our lips" (2009: 127). As mentioned earlier, the interference of the other senses weakens the primacy of the visual, hence the full effect of objectification is worn down as well.

I would like to finish my essay by mentioning a couple of very short stories in the collection, "Roy Lichtenstein's Nudes in a Mirror: We Are Not Fake!" and "Ekphrasis", which deal even more blatantly with the artifice of vision and objectification in relation to the nude/naked body in painting and photography. There is a highly ironic and comic tone throughout both stories (especially the first one), as irony allows the author to push the limits of deconstruction much further than in most of the other stories in Nude, where subjection to a realistic and plausible narrative context imposes strict restrictions on the way the characters behave to each other - including the way they look and are looked at. This plausibility, however, is never as fixed or safe as it seems - a state of instability and dysfunction that is especially noticeable in stories such as "As I Look", where the author creates constant fissures and cracks in the construction of the main characters, their voices and their actions.

In the case of "Roy Lichtenstein's Nudes in a Mirror: We Are Not Fake!" the episode that is being narrated - through an unabashedly ironic female voice - refers to an actual event: the stabbing of Roy Lichtenstein's painting Nudes in a Mirror (1994) in 2005 by an unknown female visitor on the grounds that it was fake. The traditional object of the male gaze (a painting of a naked woman, i.e. a "nude") becomes literally alive when she is given her own voice and consciousness. The object becomes a subject. She doesn't have a name but she does have a voice, and far from being "blind" she is well aware of the surroundings of the canvas she belongs to: the space of the art gallery (the Bregenz Gallery in Austria), the security guard, and especially a woman whom she calls "Brigitte" and who suddenly turns to the canvas and stabs it. The attacker's actions are described as those of an animal, and the reaction of both the guard and the male visitor could be interpreted visually as mimicking a rape, ending with the imposition of (male) physical force and control over an instinctive (female) need to exert free will and agency:

She scratches Friedrich in the face, and he and the man wrestle her to the floor. Brigitte bites the man in the leg, gnashing like a dog. He screams and pulls off his shin, but he holds her down ... Friedrich and the man huddle on the floor over Brigitte, pinning her, until two policemen arrive and haul her away (Ní Chonchúir 2009: 90). (my emphasis)

In another very short story, "Ekphrasis", we are not offered a conventional narration but rather some of the impressions a couple of famous paintings - Manet's Le Déjeneur sur l'Herbe (1863) and Picasso's Le Déjeneur sur l'Herbe (d'àpres Édouard Manet) (1960) - as well as the cover of a Bow Wow Wow record provoke in an unknown narrator (probably the author herself). In her description of Manet's painting, the narrator insists upon highlighting the difference between the nude and the naked body: "This is no nude; she brazens at me from the painting, a naked, living woman" (Ní Chonchúir 2009: 31) (my emphasis). The way the narrator describes the image once again disrupts the objectification process: the woman in the painting is an object (an image), but is treated as a "real" woman, a privilege that the woman in the Picasso painting is denied. Indeed, in this painting the image-object is surrounded with food comparisons, ${ }^{10}$ and she is insistently identified with the word "nude":

Something on the front right of the scene has caught the nude's interest: it might be one of the limes/lemons/grapefruit. Is she hungry, or suffering from scurvy and therefore craving the juicy citrus flesh? Or she may want to nab he frock from under the fruit and that shell-like, cabbagey thing, so that she can dress and leave? (Ní Chonchúir 2009: 32).

10. Similarly to what can be seen in the paintings mentioned in "As I Look", throughout the text food/flesh is assimilated to the female body with strong sexual connotations. 
In the narrator's commentary on Bow Wow Wow's record cover ${ }^{11}$ there is also a sharp criticism of the nude - even in spite of the narrator's highly ironic voice. Here we can find most of Nussbaum's conditions for objectification (instrumentality, denial of autonomy, denial of subjectivity, inertness and, most clearly, ownership):

Her real name is like Myan Myan Mar or something; she's from the Burmese jungle, I heard. Hence the tan. Anyway, Bow Wow Wow's manager said she'd never get anywhere in the music biz with a mad name like Mar Mar, or whatever it was, so he changed it. He changed it, not her! (Ní Chonchúir 2009: 33). (emphasis in the original)

The (male) manager thinks for the girl, speaks for her, and also decides for her. She is effectively reduced to a "blind" object: ${ }^{12}$ an image on a record cover. This time Ní Chonchúir does not give the character a voice but simply exposes the objectification process the girl goes through - and which extends far beyond the mere appearance of her naked body in a record cover.

\section{Conclusions}

From the analysis I have presented in this study, it seems clear that Nuala Ní Chonchúir is well

11. The cover consists of a photograph of the band posing as the characters in Manet's famous painting (Le Dejeneur sur l'Herbe), the girl posing nude while her male bandmates are dressed in bright colourful clothes.

12. Annabella Lwin (the girl mentioned in this section of "Ekphrasis") was the lead singer of Bow Wow Wow from 1980 to 1983 . At the time of the controversial LP cover mentioned in Ní Chonchúir's story, she was only 14 years old. aware of sexual objectification in western art and culture. She manages to create an "alternative gaze" that is non-objectifying and yet does not deny objectification. This she achieves, from my point of view, by blurring the frontiers around questions such as: who looks/is looked at, how he/she gazes, and who writes the body/whose body is written.

The author's sexualized narration of the body precisely stresses the importance of the naked body over the nude (in connection with - but not restricted to - the dichotomy pornography/erotica) as a means to overcome objectification and the limited scope imposed by the aestheticized body in visual culture. This approach to nudity harks back to Martha Nussbaum's "blurred" concept of objectification, as opposed to Andrea Dworkin's more fixed and unilateral point of view.

Although the female naked body is the main focus in most of her stories, Ní Chonchúir also describes the male naked body being looked at, most noticeably in "Jackson and Jerusalem". In her depictions of the male body the author allows the subject being looked at to retain his voice, his autonomy and his agency, thus dodging the traps of voyeurism and visual pleasure.

Ní Chonchúir writes the body from a distance but never gets too far away: either as an implied author or through her characters' voices she gets close enough to problematize the gaze and question assumptions and conventions on visual representation and objectification, revealing in the process the extent to which feelings, sex and instincts disrupt the false stability imposed by heteronormative systems upon the way we see our bodies and other people's bodies.

\section{Works Cited}

Berger, John. 1972. Ways of Seeing. London: Penguin.

Dworkin, Andrea. 1989 (1979). Pornography. Men Possessing Women. Middlesex/ New York: PLUME (Penguin Books).

Fredrickson, Barbara and Tomi-Ann Roberts. 1997. “Objectification Theory. Towards Understanding Women's Lived Experiences and Mental Health Risks”. Psychology of Women Quarterly, 21. 173-206.

Grosz, Elizabeth. 1990. Jacques Lacan: A Feminist Introduction. London/New York: Routledge.

Jones, Amelia. 2003. The Feminist and Visual Culture Reader. London/New York: Routledge. 
Mackinnon, Catherine and Andrea Dworkin. 1988. Pornography and Civil Rights: A New Day for Women's Equality. Minneapolis: Organizing Against Pornography.

Mulvey, Laura. 1999 (1975). "Visual Pleasure and Narrative Cinema”. Film Theory and Criticism. Eds. Leo Braudy and Marshall Cohen. New York: Oxford U.P. 833-44.

1999 (1981). “Afterthoughts on 'Visual Pleasure and Narrative Cinema' inspired by King Vidor's Duel in the Sun". Feminism and Film Theory. Ed. Sue Thornham. New York: New York U.P. 122-30.

Nead, Lynda. 1992. The Female Nude. London/New York: Routledge.

Ní Chonchúir, Nuala. 2009. Nude. London: Salt.

Nussbaum, Martha. 1995. “Objectification”. Philosophy and Public Affairs, 24:4. 249-91.

Papadaki, Evangelia. 2007. "Sexual Objectification: From Kant to Contemporary Feminism". Contemporary Political Theory, 6. 330-48.

Silverman, Kaja. 1988. The Acoustic Mirror: The Female Voice in Psychoanalysis and Cinema. Theories of Representation and Difference. Indiana: Indiana U.P

Received 30 October 2015 Last version 8 January 2016

Máximo Aláez is a researcher in the fields of literature, visual arts and gender studies at the University of Oviedo, Spain. He obtained his PhD degree in this University in 2013, and has an MA degree in Gender and Women's Studies, as well as a BA degree in English Philology (University of Oviedo) and in Fine Arts (University of Seville). 